\title{
Consumer Social Responsibility: a New Barrier for International Marketers?
}

\author{
Jieqiong (Jeccy) Ma and Jie Yang
}

\begin{abstract}
As global consumers are more aware of the social consequences of their purchases, will consumer social responsibility become a new barrier for international marketers? To answer this question, we conduct a survey on 210 American consumers and find that consumers with high social responsibility tend to have negative attitudes towards foreign products. In addition, demographic segmentation such as gender, income, and race would strengthen such observation. Consumers' age and education have little impact on this trend. Marketing implications and future research directions are provided.
\end{abstract}

References available upon request.

J.(. Ma $(\bowtie) \bullet J$. Yang

Saint Louis University, Saint Louis, MO, USA

e-mail: jma17@slu.edu; jieyang@slu.edu 